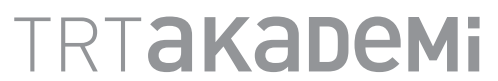

ISSN 2149-9446 | Cilt 06 | Sayı 12 | Mayıs 2021 | Dijital Hayat ve Etik

\title{
Türkiye'de Dijitalleşme Olgusuna İlişkin Bibliyografya ve Bir Değerlendirme
}

\section{Ali Hasan HAMUT*}

Insanlık tarihi açısından yeni bir kavram olarak değerlendirilebilecek olan dijitalleşme; toplumsal, ekonomik, siyasi ve kültürel alanlarda önemli etkiler oluşturmaya başlamıştı. 20.yüzyılın ortalarından itibaren elektronik sistemlerin yanı sıra bilgisayarların üretim alanına katılması birçok yenilik getirmiştir. "Bugün iletişim teknolojilerinin üretimin her aşamasında kullanılmaya başlanması, yaşanmış olan dönüşümlerin kırılma noktalarını oluşturmuştur" ("Dijital Türkiye Yol Haritası", 2018 , s.2). Hayatın her alanının dijital ortam üzerinden yürütülmeye başlanmasının kamu, özel ve sivil toplum sektörleri dahil olmak üzere kapsayıcı değişimi getiren düzenleme ve iş pratiklerini ortaya koyduğu gibi bu yeni olgunun akademik çalışmalara konu olması da giderek artan bir ivme kazanmaktadır. Dünyadaki gelişmelere paralel olarak Türkiye'nin bilgi toplumu tartş̧maları bağlamında $1980^{\prime}$ lerin sonu ve 1990 'larda yürüttüğü çabalar ve çalışmalar, 2000'li yıllara gelindiğinde kapsayıcı ve bütünsel bir dijital dönüşüm projesine dönüşmüştür: Türkiye e-Dönüşüm Projesi. Bu proje ile amaçlananlar arasında Avrupa Birliği ile bilgi ve iletişim teknolojilerinin müktesebat açısından uyarlanması, vatandaşların bilgi ve iletişim teknolojileri yardımıyla kamusal hizmetlerinden daha iyi faydalanması, kamu idaresinin daha şeffaf bir hâle getirilmesi, bilgi teknolojilerinin yaygınlaştrııması, vb. gibi ilkeler yer almaktadır. 2003 yııında 58. Hükûmet tarafindan hazırlanan Acil Eylem Planında e-Dönüşüm Türkiye Projesine (2003) adı ile kamu hizmetlerinin dijitalleşme sürecini geliştirmesi amacıyla stratejik düzeyde bir kamu politikası olarak hayata geçirilmeye başlanılan dijitalleşme süreci, salgının zorunlulukları ile birlikte eğitimden sağlığa, ticaretten hukuka hayatın tüm alanlarının işlemek durumunda olduğu bir hayat alanına dönüşmüş durumdadır. 
Türkiye'de kamu yönetimi açısından bakıldığında ise teknolojik gelişme bağlamında dijitalleşmenin önemi ve değerini 1960 'lı yıllardan itibaren kalkınma planlarında görmek mümkündür. Siyasi, ekonomik, toplumsal ve kültürel boyutlarıyla dört ana eksende planlı kalkınmanın 1963 yılından itibaren yürütülen uzun vadeli hedefleri açısından Türkiye'nin ana gündemlerinden birisinin teknoloji ve bilgi iletişim teknolojileri olduğunu söylemek abartı olmayacaktır. Şu anda yürürlükte olan On Birinci Kalkınma Planı́nda (2019-2023) da dijitalleşme konusunu ilk defa değerlendirmeye "Sanayi'de dijitalleşme" olarak alınmıştır (11. Kalkınma Planı, 2018). Kalkınma Planı dışında Bilim Sanayi Teknoloji Bakanlığı tarafindan Dijital Türkiye'nin Yol Haritası (2018) başlığı altında müstakil bir rapor hazırlanmıştır. Bu raporda kapsamlı olarak ele alınan dijitalleşmenin hem ülke politikaları hem Türkiye'deki mevcut durum hem de çeşitli bileşenleri (insan, teknoloji, altyapı, tedarikçiler, kullanıcılar, yönetişim) açısından yol haritaları belirlenmiştir.

Bu çabaların sonucunda dijitalleşmede Türkiye'nin dünya genelinde ne durumda olduğuna dair önemli bir rapor da Bilişim Sanayicileri Derneği (TÜBSIAD) tarafindan Türkiye'nin Djitalleşme Endeksi Raporu'nda (2020) açıklanmıştır. 139 ülkenin analiz verileriyle oluşturulan raporda, Türkiye'nin dijital dönüşüm endeksi 1 ile 5 arasında bir puanlamanın yapıldığı bu raporda 2019'da 2,94, 2020'de ise 3.06 olarak Türkiye'nin dijitalleşme notu tanımlanmıştır. Dijitalleşme notu "ekosistem bileşeni", "yeterlik bileşeni", "kullanım bileşeni" ve "dönüşüm bileşeni" puanlarının ortalaması alınarak oluşturulmuştur. Dijital Türkiye Platformu ve PwC (Pricewaterhousecoopers) tarafindan ortak hazırlanmış olan Dijitalleşme yolunda Türkiye raporunda ise siber güvenlik ve yapay zekâ konularına dikkat çekilmiştir. Yapay zekâ gibi yeni alanların endüstri ve tüm diğer işletmelerde ciddi bir oranda değişiklikler beklediklerini sunmuşlardır. Türkiye Bilişim Vakfinın Türkiye Dijitalizasyon Endeksi (2015) çalışmasında ise 'Finansal Hizmetler' dijitalleşme performansı en yüksek sektör olarak ortaya konulmuştur.

İnsanlık tarihi açısından da Türkiye'nin yaşadığı tarihi tecrübe açısından da kapsayıcı ve yapısal bir dönüşümü ortaya koyan dijitalleşme olgusunun Türkiye'de akademik çalışmalara ve araştırmalara konu olmasının izini sürmek için bu çalışmada, "dijital”, "dijitalleşme”, "dijital etik", "dijital medya”, "dijital teknoloji”, "dijital ortam" ve "dijital dönüşüm", anahtar kelimeleri ile tez.yok.gov.tr, dergipark.org.tr ve Google arama motorlarından 17 Nisan 2021 tarihinde yapılan arama tarama sonucunda ulaşılan rapor, tez ve makalelerin tespiti ve bibliyografik bir analizi yapılmaya çalışılmıştır. İlk olarak son zamanlarda kamu ve sivil toplum kuruluşları tarafindan yapılmış olan "dijitalleşme" temalı raporların bir özeti sunulacaktır. TRT Akademi derginin "dijital hayat ve etik" temasına uygun olduğunu düşündü- 
ğümüz makalelerin çalışma alanlarına dair bir değerlendirmesi yapılmış ve belirlenen anahtar kelimeleri içeren lisansüstü tezlerin bir künyesi oluşturulmuştur.

Türkiye'de akademik çalışmaların makaleler boyutuyla takibi ve incelenmesi açısından önemli bir veri kaynağı olan ULAKBIM-Dergipark üzerinden "dijitalleşme, dijital, dijital dönüşüm, dijital ortam, dijital medya, dijital teknoloji, dijital diplomasi, dijital kimlik, dijital eğitim, dijital sanat, dijital çağ, dijital oyun ve dijital pazarlama anahtar kelimelerle yapılan taramada yayımlanmış akademik makalelere baktığımız zaman "dijitalleşme” temalı 333 makaleye ulaşılmıştır. Bu makalelerin 230'u araştırma makalesi, 44'ü derleme, 10’u konferans bildirisi, 3’ü olgu sunumu, 3'ünün kitap incelemesi olduğu görülmektedir. Yayınlanma tarihlerine baktığımız zaman ise 2013 sonrasında "dijitalleşme" temalı makalelerin çoğunluğu oluşturduğu dikkati çekmektedir. Bu makalelerin alanlarına dikkat ettiğimiz zaman ise büyük bir çoğunluğunun sosyal bilimler kategorisinde olduğu özellikle iletişim, işletme, iktisat, sanat ve sosyoloji alanlarında olduğu görülmektedir. Yine "Dergipark" üzerinden "dijital" temalı makalelere baktığımız zaman 3765 "dijital" temalı makalenin olduğu ve yoğunluğun yine 2013 sonrası ve sosyal bilimler alanında ele alınmış olduğu ortaya çıkmaktadır. Diğer temalara baktı̆ımız zaman, "dijital ortam" temalı 35 makale, "dijital medya" temalı 139 makale, "dijital teknoloji" temalı 70 makale, "dijital diplomasi" temalı 23 makale, "dijital kimlik" temalı 9 makale, "dijital eğitim" temalı 19 makale, "dijital sanat" temalı 46 makale, "dijital çağ" temalı 91 makale, "dijital oyun" temalı 157 makale ve "dijital pazarlama" temalı 81 makale bulunmaktadır.

Türkiye'de yapılmış "dijitalleşme", "dijital", "dijital dönüşüm", "dijital ortam", "dijital medya", "dijital teknoloji", "dijital diplomasi", "dijital kimlik", "dijital eğitim", "dijital sanat", "dijital çağ", "dijital oyun", "dijital pazarlama" ve "dijital etik" gibi temalarda "Ulusal Tez Merkezi" üzerinden yapılmış tezlere bakılmıştır. Taramada konu ile ilgili tezlerin çalışma dışında kalmaması için "tümü" seçeneği seçildiği zaman "dijital" temalı 7019 tez, "dijitalleşme" temalı 513 tez bulunmaktadır. Dijitalleşme temalı ilk tezin 2001 yılında mimari alanında yazıldığı görülmektedir. (Karabağ, 2001) Akademik tezlerin isimlerine baktığımız zaman ise "dijital" ismi geçen 1592, "dijitalleşme" ismi geçen 71, "dijital dönüşüm" ismi geçen 67, "dijital ortam" ismi geçen 44, "dijital medya" ismi geçen 49, "dijital teknoloji" ismi geçen 36, "dijital diplomasi" ismi geçen 6, "dijital kimlik" ismi geçen 5, "dijital eğitim"ismi geçen 4, "dijital sanat" ismi geçen 16, "dijital çağ" ismi geçen 39, "dijital oyun" ismi geçen 139, "dijital pazarlama" ismi geçen 67 tez bulunmaktadır. Bunların dışında dergi sayımızın ana konusu olan "dijital etik" ismiyle tez olmamasına karşın, "dijital etik" temalı 3 tez bulunmaktadır. 
Çalışmanın sonunda ana temamıza uygun olduğunu düşündüğümüz "dijital etik" temalı ve "dijitalleşme”, “dijital dönüşüm”, “dijital medya”, "dijital ortam” ve "dijital teknoloji” ismi geçen lisansüstü tezlerin literatüre katkı sunmak için bir künyesi oluşturulmuştur. "Dijital Etik" temalı lisansüstü tezlere baktı̆ımız zaman ilk dikkat çeken hususun, sayısal olarak dijitalleşme ile ilgili yapılan tezlerden nicelik olarak geride kalmış olmasıdır. Dijitalleşmenin bir anda yoğun olarak sisteme entegre olmasına karşın, etik açısından yarattı̆̆ ya da yaratacağı sorunlar henüz dikkatleri çekmemektedir. Söz konusu olan üç tezde "dijital etik" teması bağlamında aramamızda bulunmasına rağmen ana konularının dijital etik olmadığı görülmektedir (Sari, 2019, Gölge, 2017, Elçi, 2015).

"Dijitalleşme” ismi geçen lisansüstü tezlere baktı̆ımız zaman ana konu dijitalleşmenin ve teknoloji kullanımının artmasının kurumalara katkısının değerlendirmesi olarak görülmektedir. Bu yüzden dijitalleşmenin çalışıldığı alanların çoğunluğunu "işletme" ve "bankacılık" oluşturmaktadır. "Dijital Dönüşüm" ismi geçen lisansüstü tezlere baktığımız zaman dijital dönüşüme engel olarak ortaya çıkan sorunların ele alındığı görülmektedir. Yine "işletme" ve "bankacılık" alanlarının ağılığı görülse de "dijital dönüşüm" ismi geçen lisansüstü tezlere "endüstri" alanını da eklemek gerekmektedir. Endüstrideki dijital gelişmelerin kurumları ve yönetimleri nasıl etkilediği ya da katkılarını analiz eden çalışmalar bulunmaktadır. "Dijital Medya” ismi geçen lisansüstü tezlere bakıldığı zaman büyük bir çoğunluğunun iletişim fakültesi merkezinde olduğu görülmektedir. Çalışmaların alanları geleneksel medya ile dijital medya arasındaki farklar, dijital medyada gazetecilik ve sosyal medyanın aşırı kullanılması ile daha da önemli hâle gelen dijital medya okuryazarlığı konularında ele alındığı görülmektedir. "Dijital Ortam" ismi geçen lisansüstü tezlere bakıldığı zaman yoğunluğun "güzel sanatlar" ve "mimarlık" alanlarında yapılan çalışmaların dijital ortamda yapılmaya başlanması ile ortaya çıkan durumlar üzerine olduğu görülmektedir. "Dijital Teknoloji" ismi geçen lisansüstü tezlere bakıldığı zaman belirli bir alanda yoğunluk görülmemektedir. Dijital teknolojinin ilgili alanlara nasıl katkıları sağladığı ve ne gibi problemler ortaya çıkardığına dair tezler olduğu görülmektedir.

Türkiye'de hem kurumların hem akademik çalışmaların son on yıldır dijitalleşme çalışmalarına ağırlık verdiği ortada olmasına karşın dijitalleşmenin sosyal ilişkilere ve toplumsal yapılara olabilecek olumsuz etkilerini öngörmeye çalışan çalışmaların az olduğu söylenebilir. Hukuki olarak da yeni bir alan olan dijital dünya birtakım kişisel hak sorunlarını gündeme getirebilmekte mevcut yasalarında yetersiz kalabildiği gözlenmektedir. Çalışmaların genel niteliği dijitalleşmenin faydalarına ve optimumuna odaklanmakta olduğu görülmektedir. "Dijital etik" temalı üç tez bulunuyor ve bu tezlerin de esas hedefi dijitalin etik problemleri olmadığından da görülebileceği gibi önümüzdeki dönemde bu konulara daha fazla yer ayrılacağı öngörülebilir. 


\section{Türkiye'de Dijitalleşme Olgusuna İlişkin Bibliyografya}

Dijitalleşme çalışmalarına katkı sağlaması amacıyla "dijital etik" temalı, "dijitalleşme”, “dijital dönüşüm”, "dijital medya”, "dijital ortam" ve "dijital teknoloji” isimli tezlerin literatüre katkı sunmak amacıyla bir künyesi oluşturulmuştur. Önce kavramlarla alakalı yüksek lisans tezleri, daha sonra doktora tezleri ve son olarak da tıpta uzmanlık ve sanatta yeterlik temalı tezler ayrı kategoriler hâlinde ve yapılış tarihi dikkate alınarak künyeleri oluşturulmuştur.

\section{A."Dijital Etik"i Konu Alan Yüksek Lisans Tezleri}

1. Gölge, A. B. (2017). "Benliğin Instagram'da çevrim içi sunumu: Türkiye'deki yoga topluluğu örneği." Yüksek Lisans Tezi. İhsan Doğramacı Bilkent Üniversitesi Ekonomi ve Sosyal Bilimler Enstitüsü.

2. Elçi, A. C. (2015). "Bilişim teknolojileri ve yazılı dersi öğretim programına yönelik öğrenci görüşlerinin dijital vatandaşlık bağlamında incelenmesi." Yüksek Lisans Tezi. Çukurova Üniversitesi Sosyal Bilimler Enstitüsü.

\section{B. "Dijitalleşme" İsminin Geçtiğini Yüksek Lisans Tezleri}

1. Yıldırım, A. C. (2020). “Dijitalleşme ve Covid-19'un bankacılık iş modeline etkileri: Türk bankaları üzerine nitel bir araştırma”. Yüksek Lisans Tezi. Orta Doğu Teknik Üniversitesi Sosyal Bilimler Enstitüsü.

2. Karabulut, C. (2020). “Dış ticarette dijitalleşme ve kağıtsıı süreç yönetimi”. Yüksek Lisans Tezi. İstanbul Ticaret Üniversitesi Dış Ticaret Enstitüsü.

3. Şükranlı, D. (2020). "Şirketin dijitalleşme seviyesinin çalışan memnuniyeti ve verimliliğine etkisi". Yüksek Lisans Tezi. Bahçeşehir Üniversitesi Sosyal Bilimler Enstitüsü.

4. Satılmış, Ç. (2020). “Dijitalleşme ve Endüstri 4.0'ın beyaz eşya sektörüne etkisi”. Yüksek Lisans Tezi. Bahçeşehir Üniversitesi Sosyal Bilimler Enstitüsü.

5. Dervişoğlu, Burak. (2020). "Pixar şirketinin, canlandırma sinemasının dijitalleşme sürecinde 3 boyutlu bilgisayar grafiklerinin kullanılmasına etkisi". Yüksek Lisans Tezi. İstanbul Aydın Üniversitesi Lisansüstü Eğitim Enstitüsü.

6. Balcı, E. (2020). "Lojistik sektörünün uluslararası alanda dijitalleşme süreci ve Türkiye'ye etkileri”. Yüksek Lisans Tezi. Marmara Üniversitesi Sosyal Bilimler Enstitüsü.

7. Kaya, I. U. (2020). “Finansal okuryazarlık ve finansal dijitalleşme ilişkisi: Bankacılık ve Finans Bölümü öğrencileri üzerine bir araştırma". Yüksek Lisans Tezi. Burdur Mehmet Akif Ersoy Üniversitesi Sosyal Bilimler Enstitüsü. 
8. Okan, M. (2020). "Yazılık sektöründe çevik dönüşüm ile dijitalleşme üzerine inceleme”. Yüksek Lisans Tezi. Bahçeşehir Üniversitesi Sosyal Bilimler Enstitüsü.

9. Avcı, B. (2020). “Dijitalleşmenin muhasebe mesleğine getirdiği yenilikler ve uygulamalar". Yüksek Lisans Tezi. İstanbul Bilgi Üniversitesi Lisansüstü Eğitim Enstitüsü.

10. Kaya, H. (2020). “Dijitalleşme sürecindeki bir hastane çalışanlarının e-sağlık sistemlerinin hizmet sunumuna etkileri konusunda bilgi, tutum ve beklentilerinin incelenmesi”. Yüksek Lisans Tezi. İstanbul Medipol Üniversitesi Sağlık Bilimleri Enstitüsü.

11. Arslaner, S. (2020). “Bankaların dijitalleşme süreçleri ve müşteri üzerindeki etkileri - bir banka uygulaması". Yüksek Lisans Tezi. Bahçeşehir Üniversitesi Sosyal Bilimler Enstitüsü.

12. Gider, M. (2020). "Turizm pazarlaması kapsamında dijitalleşme sürecinin turizm sektörü üzerindeki etkileri: Nitel bir araşttrma". Yüksek Lisans Tezi. Akdeniz Üniversitesi Sosyal Bilimler Enstitüsü.

13. İnaç, C. (2020). "Dijitalleşmenin yayınevleri üzerindeki etkisi”. Yüksek Lisans Tezi. Üsküdar Üniversitesi Sosyal Bilimler Enstitüsü.

14. Sevinç, H. N. (2020). “Dijitalleşme ve değişim algısının çalışanlar üzerindeki etkisi”. Yüksek Lisans Tezi. Bahçeşehir Üniversitesi Sosyal Bilimler Enstitüsü.

15. Yetkin, Y. (2019). "Konaklama işletmelerinde dijitalleşme ve dijitalleşmenin sürdürülebilir turizm ile ilişkisi”. Yüksek Lisans Tezi. Van Yüzüncü Yıl Üniversitesi Sosyal Bilimler Enstitüsü.

16. Arslan, A. (2019). " $X, Y$ ve $Z$ jenerasyonlarındaki dijitalleşme etkisinin marka entegrasyonu üzerine etkisi”. Yüksek Lisans Tezi. İstanbul Aydın Üniversitesi Sosyal Bilimler Enstitüsü.

17. Türk, D. (2019). “Dijitalleşmenin müzik endüstrisinde tedarik zinciri karmaşıkIığına etkisi: Türkiye'de deneysel bir çalışma”. Yüksek Lisans Tezi. Orta Doğu Teknik Üniversitesi Sosyal Bilimler Enstitüsü.

18. Yıldız, K. (2019). “Dijitalleşme ve operasyonel verimlilik arasındaki ilişki: Türk telekomünikasyon endüstrisinden kanıt". Yüksek Lisans Tezi. Bahçeşehir Üniversitesi Sosyal Bilimler Enstitüsü.

19. Özkurt, Ö. (2019). “Dijital dönemde müzik endüstrisi: dijitalleşmenin Türkiye'deki müzik endüstrisine etkileri üzerine bir araştırma". Yüksek Lisans Tezi. İstanbul Teknik Üniversitesi Sosyal Bilimler Enstitüsü. 
20. Polatateş, E. (2019). “Dijitalleşmenin cinsiyet eşitsizliği üzerine etkileri”. Yüksek Lisans Tezi. Yeditepe Üniversitesi Sosyal Bilimler Enstitüsü.

21. İnce, G. (2019). “Dijitalleşmenin şirket performansına etkisi”. Yüksek Lisans Tezi. Bahçeşehir Üniversitesi Sosyal Bilimler Enstitüsü.

22. Atik, Ö. Z. (2019). "Eğitimde dijitalleşme faaliyetleri ve eğitim yöneticilerinin sürece uyumu". Yüksek Lisans Tezi. İstanbul Aydın Üniversitesi Sosyal Bilimler Enstitüsü.

23. Bozkurt, A. (2019). “Türkiye'de e-devlet uygulamaları ve dijitalleşme”. Yüksek Lisans Tezi. Hatay Mustafa Kemal Üniversitesi Fen Bilimleri Enstitüsü.

24. Uzun, L. N. (2019). “Dijitalleşmenin hemşirelik uygulamalarına harcanan zamana ve hasta güvenliğine etkisinin yalın hastane yaklaşımıyla incelenmesi". Yüksek Lisans Tezi. Bolu Abant İzzet Baysal Üniversitesi Sağlık Bilimleri Enstitüsü.

25. Akkan, G. (2019). "Tüketici ürünlerinde dijitalleşme ve internetin kullanıcı deneyimine etkileri: Bir çamaşır makinesi üzerinden inceleme”. Yüksek Lisans Tezi. Mimar Sinan Güzel Sanatlar Üniversitesi Fen Bilimleri Enstitüsü.

26. Eroğlu, Ö. (2019). “Ritüellerin dijitalleşmesi: Mobil cihazlardaki kahve falı uygulamalarının arayüz ve deneyim tasarımları üzerine bir inceleme". Yüksek Lisans Tezi. İstanbul Teknik Üniversitesi Fen Bilimleri Enstitüsü.

27. Tekin, S. (2019). “Bankacılıkta dijital gelişmeler ve müşterilerin dijitalleşmeye uyumu ve analizi”. Yüksek Lisans Tezi. Necmettin Erbakan Üniversitesi Sosyal Bilimler Enstitüsü.

28. Karakaş, Y. (2019). “Dijitalleşmenin modern gündelik hayata yansımaları ve hikikomori örneği”. Yüksek Lisans Tezi. Ankara Hacı Bayram Veli Üniversitesi Lisansüstü Eğitim Enstitüsü.

29. Barlas, N. (2019). "Siyasal iletişimde dijitalleşme: 24 Haziran 2018 Cumhurbaşkanlığı seçimleri üzerine karşılaştırmalı bir Twitter analizi”. Yüksek Lisans Tezi. Kadir Has Üniversitesi Lisansüstü Eğitim Enstitüsü.

30. Yasacı, S. (2019). "Türkiye'de dijitalleşme bağlamında okuma alışkanlıklarının gelişimi: Sesli kitaplar örneği”. Yüksek Lisans Tezi. Marmara Üniversitesi Sosyal Bilimler Enstitüsü.

31. Şefii, Ş. (2019). "Kentlerin dijitalleşmesinin sinemada temsili”. Yüksek Lisans Tezi. İstanbul Üniversitesi Sosyal Bilimler Enstitüsü.

32. Yılmaztürk, N. (2019). "Yoğun bakım ünitelerinde tıbbi kayıtların dijitalleşme- 
sinin iş süreçlerine etkisi”. Yüksek Lisans Tezi. İstanbul Medipol Üniversitesi Sağlık Bilimleri Enstitüsü.

33. Ustaömer, K. (2019). “Türkiye'nin bankacılık sektöründe dijitalleşme olgusu (Özel bankalar örneği)”. Yüksek Lisans Tezi. Sakarya Üniversitesi Sosyal Bilimler Enstitüsü.

34. Sayar, S. (2019). “Dijitalleşme ile yeni oluşan kavramlar: Endüstri 4.0, ıt ve blockchain uygulamaları". Yüksek Lisans Tezi. Maltepe Üniversitesi Sosyal Bilimler Enstitüsü.

35. Gündüz, B. E. (2019). “Dijitalleşmenin müzik endüstrisine etkileri: Spotify örneği”. Yüksek Lisans Tezi. Maltepe Üniversitesi Sosyal Bilimler Enstitüsü.

36. Çakmak, C. (2018). “Dijitalleşmenin gelecekte bankacılık sektörüne etkileri”. Yüksek Lisans Tezi. Bahçeşehir Üniversitesi Sosyal Bilimler Enstitüsü.

37. Durakoğlu, İ. (2018). "Müzenin dijitalleşmesi: Sakıp Sabancı Müzesi örneği”. Yüksek Lisans Tezi. İstanbul Bilgi Üniversitesi Sosyal Bilimler Enstitüsü.

38. İlhan, E. C. (2018). "Eylemlerin dijitalleşmesi: e-kitap okuyucuların fiziksel ve dijital özellikleri üzerinden anlam bilimsel analizi". Yüksek Lisans Tezi. İstanbul Teknik Üniversitesi Fen Bilimleri Enstitüsü.

39. Tekbaş, i. (2018). “Dijitalleşmenin muhasebe mesleğine ve meslek mensuplarına etkileri üzerine bir araştırma ve yeni bir kavram önerisi: Mali mühendislik". Yüksek Lisans Tezi. İstanbul Okan Üniversitesi Sosyal Bilimler Enstitüsü.

40. Özdemir, O. (2018). "Otomobil sektöründe satış sonrası hizmetlerde (servis) değişim ve dijitalleşme". Yüksek Lisans Tezi. Bahçeşehir Üniversitesi Sosyal Bilimler Enstitüsü.

41. Akgöl, O. (2018). "Spor endüstrisi ve dijitalleşme: Türkiye'de E-spor yapılanması üzerine bir inceleme". Yüksek Lisans Tezi. İstanbul Üniversitesi Sosyal Bilimler Enstitüsü.

42. Kazan, ì. (2018). "Türkiye bankacılık sektöründe kanalların ve pazarlama enstrümanlarının dijitalleşmesinin müşteri satın alma davranışı üzerindeki etkisi". Yüksek Lisans Tezi. Bahçeşehir Üniversitesi Sosyal Bilimler Enstitüsü.

43. Koç, P. (2018). "Akademisyen dijitalleşme ölçeğinin geliştirilmesi”. Yüksek Lisans Tezi. Süleyman Demirel Üniversitesi Eğitim Bilimleri Enstitüsü.

44. Yılmaz, N. (2018). “Türkiye'de dergi yayıncılığının dijitalleşmesi”. Yüksek Lisans Tezi. İstanbul Aydın Üniversitesi Sosyal Bilimler Enstitüsü. 
45. Yıldız, C. K. (2018). "Lüks tüketim pazarında dijitalleşmenin etkileri". Yüksek Lisans Tezi. Bahçeşehir Üniversitesi Sosyal Bilimler Enstitüsü.

46. Kutluay, B. K. (2017). “Dijitalleşme, yeni nesil teknolojiler ve finans üzerine etkileri”. Yüksek Lisans Tezi. Yeditepe Üniversitesi Sosyal Bilimler Enstitüsü.

47. Kaşifoğlu, G. (2017). “Dijitalleşmenin açık hava reklamlarında interaktiviteyi sağlamadaki rolü". Yüksek Lisans Tezi. İstanbul Ticaret Üniversitesi Sosyal Bilimler Enstitüsü.

48. Yandım, D. (2017). "Yeni iletişim ortamlarının ekonomi politiği bağlamında emeğinin dijitalleşmesi üzerine bir araştırma". Yüksek Lisans Tezi. Marmara Üniversitesi Sosyal Bilimler Enstitüsü.

49. Tezcan, E. T. (2017). "Halkla ilişkilerin dijitalleşmesi bağlamında konum tabanlı pazarlama". Yüksek Lisans Tezi. İstanbul Aydın Üniversitesi Sosyal Bilimler Enstitüsü.

50. Gedik, E. (2017). “Endüstrisi ürünleri tasarımında dijitalleşme: Üç boyutlu baskı teknolojilerinin ürün tasarım pratiğinde kullanımı". Yüksek Lisans Tezi. Gazi Üniversitesi Fen Bilimleri Enstitüsü.

51. Aslan, Eren (2017). “Reklam iletişiminde dijitalleşme: Online davranışsal reklam kavramı ve tasarım". Yüksek Lisans Tezi. İstanbul Kültür Üniversitesi Sosyal Bilimler Enstitüsü.

52. Ülke, Y. B. (2016). “Kitap yayıncılığı endüstrisinin dijitalleşmesi: Türkiye'deki e-kitap yayıncılığı üzerine bir çalışma”. Yüksek Lisans Tezi. Yeditepe Üniversitesi Sosyal Bilimler Enstitüsü.

53. Demirel, S. (2016). "Sinema teknoloji ilişkisi: Ses, renk, geniş perde, dijitalleşme ve üç boyutun anlatıma katkıları". Yüksek Lisans Tezi. Ankara Üniversitesi Sosyal Bilimler Enstitüsü.

54. Yanık, N. E. (2015). “Müziklemenin dijitalleşmesi: dijital medya müzikal aktivite biçimlerine nasıl müdahil olmaktadır?". Yüksek Lisans Tezi. İstanbul Bilgi Üniversitesi Sosyal Bilimler Enstitüsü.

55. Aydoğan, D. (2014). "Türk romanında dijitalleşme: E-kitap”. Yüksek Lisans Tezi. İstanbul Kültür Üniversitesi Sosyal Bilimler Enstitüsü.

\section{C. "Dijital Medya" İsminin Geçtiği Yüksek Lisans Tezleri}

1. Enehasse, A. (2020). “Dijital medya pazarlamasının tüketici davranış niyeti üzerindeki etkisi: Marka güveninin düzenleyici rolü”. Yüksek Lisans Tezi. İstanbul Ti- 
caret Üniversitesi Sosyal Bilimler Enstitüsü.

2. Aytuna, D. (2020). "Fiziksel ve dijital medya arasındaki oyuncu deneyimi farkları / 'Magic: The Gathering' örnek çalışma”. Yüksek Lisans Tezi. Kadir Has Üniversitesi Lisansüstü Eğitim Enstitüsü.

3. Said, S. B. S. (2020). “Yeni medyada propaganda, ‘Orta Doğu'daki Arap kamuoyuna doğru dijital medyada İsrail propagandisti söylemi”. Yüksek Lisans Tezi. Kocaeli Üniversitesi Sosyal Bilimler Enstitüsü.

4. Korkmaz, Ö. E. (2020). “Geleneksel kitle iletişim araçlarından dijital medyaya geçiş sürecinde değişen seçmen davranışları: Kuşaklar üzerine bir araştırma". Yüksek Lisans Tezi. İstanbul Aydın Üniversitesi Lisansüstü Eğitim Enstitüsü.

5. Fıstık, F. (2020). “Dijital medyada değişen çalışma koşulları ve serbest gazetecilik". Yüksek Lisans Tezi. Marmara Üniversitesi Sosyal Bilimler Enstitüsü.

6. Acar, H. A. (2020). "Dijital medya ürünleri ve markalarıyla olan ilişkilerimiz". Yüksek Lisans Tezi. Akdeniz Üniversitesi Sosyal Bilimler Enstitüsü.

7. Saman, S. (2020). “Dijital medya ve reklamcılık: Türkiye örneğinde dijital reklamcılık ve dijital reklamcılıkta programatik reklamların rolü”. Yüksek Lisans Tezi. Bahçeşehir Üniversitesi Sosyal Bilimler Enstitüsü.

8. İçli, A. (2020). "Dijital medya kullanımı açısından Türkiye'de e-spor izleyiciliği”. Yüksek Lisans Tezi. Marmara Üniversitesi Sosyal Bilimler Enstitüsü.

9. Böyük, M. (2020). "Sosyal ve dijital medya üzerinde dijital kolonyalizm uygulamaları ve habercilik". Yüksek Lisans Tezi. Erciyes Üniversitesi Sosyal Bilimler Enstitüsü.

10. Tuğtekin, P. (2020). “Dijital medyada televizyon dizilerinin değişen zaman ve mekân kurgusu: (Puhu TV) 'Şahsiyet' dizisi örneği'”. Yüksek Lisans Tezi. Başkent Üniversitesi Sosyal Bilimler Enstitüsü.

11. Çakıcı, Z. (2020). "Uluslararası dijital medyada bir sosyal temsil olarak Aylan Kurdi haberleri". Yüksek Lisans Tezi. Galatasaray Üniversitesi Sosyal Bilimler Enstitüsü.

12. İpek, S. (2019). “Dijital medyadaki sağlık haberlerinin güvenilirliğine ilişkin bir araştırma”. Yüksek Lisans Tezi. İstanbul Bilgi Üniversitesi Sosyal Bilimler Enstitüsü.

13. Duru, M. E. (2019). "Siyasal iletişim faaliyetlerinde dijital medya kullanımı: 31 Mart 2019 Yerel Seçimleri'nde partilerin internet sitelerinin incelenmesi". Yüksek Lisans Tezi. Akdeniz Üniversitesi Sosyal Bilimler Enstitüsü. 
14. Yağmur, T. A. (2019). “Dijital medya ile değişen haber tüketim tercihleri ve haber doğrulama davranışları üzerine bir araştırma". Yüksek Lisans Tezi. Üsküdar Üniversitesi Sosyal Bilimler Enstitüsü.

15. Winegard, E. (2019). "Dijital medya teknolojilerinin sanatın ve tasarımın yaygınlaşmasındaki yeri ve önemi”. Yüksek Lisans Tezi. İstanbul Üniversitesi Sosyal Bilimler Enstitüsü.

16. Başmanav, N. (2019). “Michel Foucault'nun beden algısı ve kültürel dönüşüm süreçlerinden hareketle moda kavramı ve lüks markaların dijital medya evrimi". Yüksek Lisans Tezi. Galatasaray Üniversitesi Sosyal Bilimler Enstitüsü.

17. Erim, S. (2019). “Dijital medyada yorumların marka kredibilitesi, marka tutumu ve satın alma niyetine etkisi üzerine bir araştırma”. Yüksek Lisans Tezi. Marmara Üniversitesi sosyal Bilimler Enstitüsü.

18. Boztepe, E. (2019). "Yazılı basından dijital medyaya yeni reklam pratikleri”. Yüksek Lisans Tezi. Kocaeli Üniversitesi Sosyal Bilimler Enstitüsü.

19. Simavoğlu, F. (2019). “Dijital medya reklamlarının z jenerasyonun çevrim içi satın alma davranışları üzerindeki rolü”. Yüksek Lisans Tezi. Selçuk Üniversitesi Sosyal Bilimler enstitüsü.

20. Ayerdem, T. İ. (2019). "Türkiye'deki dijital medya platformları ve izler kitle profili". Yüksek Lisans Tezi. İstanbul Üniversitesi Sosyal Bilimler Enstitüsü.

21. Eser, A. B. (2019). “Dijital medya çağında ürün yerleştirme kavramının nüfuz pazarlamasına evrilmesi". Yüksek Lisans Tezi. Beykent Üniversitesi Sosyal Bilimler Enstitüsü.

22. Abuyounis, B. A. K. (2018). “15 Temmuz darbesinin püskürtülmesinde dijital medyanın kullanımı”. Yüksek Lisans Tezi. Kadir Has Üniversitesi Sosyal Bilimler Enstitüsü.

23. Coşar, H. (2018). "Geleneksel medyadan dijital medyaya geçiş sürecinde Türkiye'de medya ve reklam yatırımlarının değişen yapısı". Yüksek Lisans Tezi. Marmara Üniversitesi Sosyal Bilimler Enstitüsü.

24. Sıvar, İ. (2018). “İnternetle değişen ticaret ve rekabet: Mikro işletmelerinin dijital medya kullanımları". Yüksek Lisans Tezi. Anadolu Üniversitesi Sosyal Bilimler Enstitüsü.

25. Tailaiti, T. (2018). “Dijital medya ve kültür endüstrisi”. Yüksek Lisans Tezi. İstanbul Ticaret Üniversitesi Sosyal Bilimler Enstitüsü.

26. Farajova, A. (2018). “Azerbaycan ve Türkiye'deki üniversite öğrencilerinin gele- 
neksel ve dijital medya kullanımları ve doyumları”. Yüksek Lisans Tezi. Bahçeşehir Üniversitesi Sosyal Bilimler Enstitüsü.

27. Yılmayan, E. (2017). “Ailelerin çocuklarının dijital medya kullanımı konusundaki tutumları". Yüksek Lisans Tezi. İstanbul Bilgi Üniversitesi Sosyal Bilimler Enstitüsü.

28. Tezeren, E. (2017). "Dijital medyada markalaşma ve sembolik tüketim ilişkisi”. Yüksek Lisans Tezi. İstanbul Bilgi Üniversitesi Sosyal Bilimler Enstitüsü.

29. Abdiyev, F. (2017). "Satın alma sürecinde dijital medya kanallarının kullanımı ve müşteri memnuniyeti: T.C. Dokuz Eylül Üniversitesi öğrencileri üzerinde bir araştırma". Yüksek Lisans Tezi. Dokuz Eylül Üniversitesi Sosyal Bilimler Enstitüsü.

30. Atıcı, S. G. (2016). “Post-fordist duygular, imajlar ve zamanlar: İstanbul'da bir dijital medya ajansındaki tedavüllerin etnografisi”. Yüksek Lisans Tezi. Boğaziçi Üniversitesi Sosyal Bilimler Enstitüsü.

31. Tunalı, E. (2016). “Dijital medyada, kullanıcı arayüz tasarımının eleştirel bir analizi". Yüksek Lisans Tezi. İhsan Doğramacı Bilkent Üniversitesi Ekonomi ve Sosyal Bilimler Enstitüsü.

32. Yanık, N. E. (2015). “Müziklemenin dijitalleşmesi: Dijital medya müzikal aktivite biçimlerine nasıl müdahil olmaktadır?". Yüksek Lisans Tezi. İstanbul Bilgi Üniversitesi Sosyal Bilimler Enstitüsü.

33. Çağdaş, H. (2014). “Örgütsel iletişimde dijital medyanın kullanımı: Görgül bir araştırma”. Yüksek Lisans Tezi. Türk Hava Kurumu Üniversitesi Sosyal Bilimler Enstitüsü.

34. Güzelkokar, M. A. (2014). “Dijital medyada fanatizm: futbola ilişkin sosyal ağlarda nefret söylemi”. Yüksek Lisans Tezi. Galatasaray Üniversitesi Sosyal Bilimler Enstitüsü.

35. Çelik, S. (2012). “Dijital medyada marka oluşturma (Marka bilinirliliği ve interaktif ajanslar ile marka yönetimi ve strateji oluşturma yöntemleri)". Yüksek Lisans Tezi. İstanbul Bilgi Üniversitesi Sosyal Bilimler Enstitüsü.

36. Orhan, Y. (2009). "Sanaldan haptik mekâna: Form ve mekânın dijital medya üzerinden yeniden düşünülmesi". Yüksek Lisans Tezi. İzmir Ekonomi Üniversitesi Sosyal Bilimler Enstitüsü.

37. İnceoğlu, F. (2003). "Dijital medyada mimari tasarım: Tasarımı tasarlamak". Yüksek Lisans Tezi. Yıldız Teknik Üniversitesi Fen Bilimleri Enstitüsü. 


\section{D. "Dijital Dönüşüm" İsminin Geçtiği Yüksek Lisans Tezleri}

1. Koç, T. H. (2020). “Kamu yönetiminde dijital dönüşüm: Türkiye'de kamu yönetiminin dijital dönüşümüne dair bir analiz". Yüksek Lisans Tezi. Avrasya Üniversitesi Sosyal Bilimler Enstitüsü.

2. Üstdağ, M. F. (2020). "Türkiye'deki dijital yerli şirketler için dijital dönüşüm engellerinin tanımlanması”. Yüksek Lisans Tezi. Bahçeşehir Üniversitesi Sosyal Bilimler Enstitüsü.

3. Haidara, O. (2020). "Dijital dönüşüme tüketici yanıtları ve dijital pazarlama stratejisi”. Yüksek Lisans Tezi. İstanbul Okan Üniversitesi Sosyal Bilimler Enstitüsü.

4. Atukeren, E. P. (2020). “Dijital dönüşüm, esnek çalışma yöntemleri; insan kaynakları verimliliği çalışması”. Yüksek Lisans Tezi. Yeditepe Üniversitesi Sosyal Bilimler Enstitüsü.

5. Kapucu, H. (2020). “Dijital dönüşümün lider davranışlarına etkisi: Ara mal endüstrisinde uygulama”. Yüksek Lisans Tezi. Bahçeşehir Üniversitesi Sosyal Bilimler Enstitüsü.

6. Bostan, M. Ö. (2020). "Depolarda dijital dönüşüm ve Endüstri 4.0 uygulamaları". Yüksek Lisans Tezi. Bahçeşehir Üniversitesi Sosyal Bilimler Enstitüsü.

7. Dağlı, Ç. K. (2020). “Endüstri 4.0 bağlamında, dijital dönüşüm sürecinde iç pazarlama uygulamaları”. Yüksek Lisans Tezi. Yeditepe Üniversitesi Sosyal Bilimler Enstitüsü.

8. Kesbiç, Ö. Ö. (2020). “Üretimde dijital dönüşüm ve etkileri: Türkiye ekonomisi açısından bir analiz". Yüksek Lisans Tezi. Manisa Celal Bayar Üniversitesi Sosyal Bilimler Enstitüsü.

9. Güngör, Ö. (2020). “E-devlet hizmetlerinin merkezi teşkilatının yeniden yapılanması: Dijital Dönüşüm Ofisi örneği". Yüksek Lisans Tezi. Akdeniz Üniversitesi Sosyal Bilimler Enstitüsü.

10. Güven, Ö. (2020). “Dijital dönüşümde blokzincir teknolojisi ve Bitcoin'in ekonomiye etkisi". Yüksek Lisans Tezi. Aydın Adnan Menderes Üniversitesi Sosyal Bilimler Enstitüsü.

11. Karagöz, U. (2020). “Türkiye'de kamu yönetiminin dijital dönüşümü: Ulusal Veri Santrali model önerisi". Yüksek Lisans Tezi. Ankara Hacı Bayram Veli Üniversitesi Lisansüstü Eğitim Enstitüsü.

12. Konya, Onur. (2020). “Büyük veri ile reklamda yaşanan dijital dönüşüm ve tüketiciye yansımaları". Yüksek Lisans Tezi. Marmara Üniversitesi Sosyal Bilimler Enstitüsü. 
13. Dökme, S. (2020). “Sakarya'da dijital dönüşüme yönelik sanayi kuruluşlarında karşılaştırmalı değerlendirme çalışması". Yüksek Lisans Tezi. Sakarya Üniversitesi Fen Bilimleri Enstitüsü.

14. Adıgüzel, Ö. (2020). "Dijital dönüşüm sürecinde e-anahtar destekli okul yönetim sistemi”. Yüksek Lisans Tezi. Süleyman Demirel Üniversitesi Fen Bilimler Enstitüsü.

15. Koçak, B. (2020). "Dijital dönüşüm ile mobil uygulamaların pazarlama faaliyetlerine katkısının ve tüketici davranışlarıyla ilişkisinin incelenmesi". Yüksek Lisans Tezi. Bahçeşehir Üniversitesi Sosyal Bilimleri Enstitüsü.

16. Evren, E. (2020). “Otomotiv sektöründe saha çalışanlarının dijital dönüşüm kapsamında güvenlik yeleği ve baretlerinin yapay sinir ağı yöntemi ile algılanması”. Yüksek Lisans Tezi. Sakarya Üniversitesi Fen Bilimleri Enstitüsü.

17. Gürbüz, U. (2020). “Şirketlerin dijital dönüşümünde İK'nin dönüştürücü rolü: Daha fazla yeteneği şirkete kazandırmak için işe alım süreçlerinde kullanılan oyunlaştırılmış değerlendirme testi üzerine bir çalışma”. Yüksek Lisans Tezi. Bahçeşehir Üniversitesi Sosyal Bilimler Enstitüsü.

18. Gözüküçük, M. F. (2020). “Dijital dönüşüm ve ekonomik büyüme”. Yüksek Lisans Tezi. İstanbul Ticaret Üniversitesi Sosyal Bilimler Enstitüsü.

19. Yıldırım, Begüm. (2020). "İşletmelerde endüstri 4.0 dijital dönüşüm süreci ve çalışan motivasyonuna etkileri”. Yüksek Lisans Tezi. Kırklareli Üniversitesi Sosyal Bilimler Enstitüsü.

20. Çobanoğlu, S. (2020). "Teknolojide dijital dönüşün bankalarda operasyonel işlemlerinde verimliliğine olan etkisi". Yüksek Lisans Tezi. İstanbul Okan Üniversitesi Sosyal Bilimler Enstitüsü.

21. Onaylı, E. (2020). “Bankacılıkta dijital dönüşümle değişen müşteri deneyiminin müşteri sadakati, müşteri memnuniyeti ve müşteri tavsiye etme niyeti üzerine etkisi". Yüksek Lisans Tezi. Bahçeşehir Üniversitesi Sosyal Bilimler Enstitüsü.

22. Kahraman,nH. (2020). "Endüstri 4.0 sürecinde lojistikte dijital dönüşüm: TRANS.EU TMS 4.0 dijital platformun incelenmesi”. Yüksek Lisans Tezi. Bandırma Onyedi Eylül Üniversitesi Sosyal Bilimler Enstitüsü.

23. Dündar, M. M. (2020) “Kobi'lerin dijital dönüşümü”. Yüksek Lisans Tezi. TOBB Ekonomi ve Teknoloji Üniversitesi Sosyal Bilimler Enstitüsü.

24. Sayın, Can. (2020). “Konut pazarlamasında dijital dönüşümün mimari tasarıma 
etkisi: Sosyal medya üzerinde paylaşılan görsellerin analizine yönelik nitel bir araşttrma”. Yüksek Lisans Tezi. Alanya Hamdullah Emin Paşa Üniversitesi Lisansüstü Eğitim Enstitüsü.

25. Aimaier, Y. (2020). “Kuşak Yol Projesine Türk firmaların bakış açısı ve dijital dönüşüm: Bir araştırma”. Yüksek Lisans Tezi. Ondokuz Mayıs Üniversitesi Lisansüstü Eğitim Enstitüsü.

26. Yavuz, A. (2020). "Turizmde dijital dönüşüm: Otel yöneticilerinin bakış açılarının incelenmesi”. Yüksek Lisans Tezi. Düzce Üniversitesi Sosyal Bilimler Enstitüsü.

27. Yılmaz, P. (2020). “Ortaöğretim öğretmenlerinin eğitimde dijital dönüşümden yararlanma düzeylerinin belirlenmesi”. Yüksek Lisans Tezi. Hacettepe Üniversitesi Eğitim Bilimleri Enstitüsü.

28. Aygün, Ö. (2020). "Yerel yönetimlerde dijital dönüşüm uygulamaları: Trabzon ili örneği”. Yüksek Lisans Tezi. Avrasya Üniversitesi Sosyal Bilimler Enstitüsü.

29. Odabaşı, E. (2020). “Örgütsel bağlılığın dijital dönüşüme dirence etkisinde liderliğin düzenleyici rolünün incelenmesi”. Yüksek Lisans Tezi. Bahçeşehir Üniversitesi Sosyal Bilimler Enstitüsü.

30. Turan, Y. (2020). “Dijital dönüşümün bankacılık sektörü iç denetim süreç mekânizmaları üzerindeki etkisi ve vaka analizi”. Yüksek Lisans Tezi. Bahçeşehir Üniversitesi Sosyal Bilimler Enstitüsü.

31. Yılmaz, E. (2020). “Dijital dönüşüm bağlamında teknolojik zehirlenme ve semptomları”. Yüksek Lisans Tezi. Marmara Üniversitesi Sosyal Bilimler Enstitüsü.

32. Ustaoğlu, N. (2019). “Dijital dönüşüm odaklı olgunluk modeli oluşturma”. Yüksek Lisans Tezi. Sabancı Üniversitesi Mühendislik ve Fen Bilimleri Enstitüsü.

33. Özdemir, S. (2019). "Yerli dijital dönüşümün sağlanması: Bt ürünlerinin menşei ülkesini belirleme metodolojisi”. Yüksek Lisans Tezi. Boğaziçi Üniversitesi Sosyal Bilimler Enstitüsü.

34. Çavuşyan, S. (2019). “Dijital dönüşüm: Ortak anlayış ve stratejik hizalama perspektifi”. Yüksek Lisans Tezi. Boğaziçi Üniversitesi Sosyal Bilimler Enstitüsü.

35. Gün, Ö. E. (2019). “Dijital dönüşüm: Kritik başarı faktörlerinin modern çalışma alanları üzerine etkisi”. Yüksek Lisans Tezi. Boğaziçi Üniversitesi Sosyal Bilimler Enstitüsü.

36. Elitok, E. (2019). “Endüstri 4.0 ile dijital dönüşüm: Türkiye örnek incelemesi”. Yüksek Lisans Tezi. Atılım Üniversitesi Fen Bilimleri Enstitüsü.

37. Uslu, C. İ. (2019). “Dijital dönüşüm çağında fonksiyon bazında yönetici karar- 
larının otomasyona geçişinin değerlendirmesi”. Yüksek Lisans Tezi. İstanbul Teknik Üniversitesi Fen Bilimleri Enstitüsü.

38. Arsal, T. (2019). “Türkiye'de yaşayan dijital dönüşümün radyo yayıncılığına etkisi: Değişen dinleyici profili". Yüksek Lisans Tezi. İstanbul Medipol Üniversitesi Sosyal Bilimler Enstitüsü.

39. Tangal, E. (2019). "Kurumsal mimari bakış açısıyla dijital dönüşüm: Gerçek bir uygulama”. Yüksek Lisans Tezi. Yıldız Teknik Üniversitesi Fen Bilimleri Enstitüsü.

40. Doğan, D. (2019). "Dijital dönüşümün yönetimi sürecinde üniversite öğrencilerinin endüstri 4.0 kavramsal farkındalık düzeyleri”. Yüksek Lisans Tezi. Kırşehir Ahi Evran Üniversitesi Sosyal Bilimler Enstitüsü.

41. Berdan, B. (2019). “Türkiye'de film yapım sürecinde dijital dönüşümün yapım şirketleri üzerindeki etkisi”. Yüksek Lisans Tezi. Marmara Üniversitesi Sosyal Bilimler Enstitüsü.

42. Sönmez, P. K. (2019). “Endüstri 4.0 \& dijital dönüşümde çalışanların değişime açıklığı ile yöneticilerinin liderlik tarzları ilişkisinin incelenmesi”. Yüksek Lisans Tezi. Bahçeşehir Üniversitesi Sosyal Bilimler Enstitüsü.

43. Uçansoy, M. (2019). “Kurumlardaki dijital dönüşümün stratejik karar alma üzerine etkileri”. Yüksek Lisans Tezi. Bahçeşehir Üniversitesi Sosyal Bilimler Enstitüsü.

44. Sevindik, E. (2019). "Habercilikte dijital dönüşüm: Çevrim içi haber videoları". Yüksek Lisans Tezi. İstanbul Üniversitesi Sosyal Bilimler Enstitüsü.

45. Güvener, A. (2019). “Dijital dönüşüm sürecinde çalışanların teknolojik hazıroluş seviyelerinin belirlenmesi”. Yüksek Lisans Tezi. Bahçeşehir Üniversitesi Sosyal Bilimler Enstitüsü.

46. Çalımlı, Y. (2019). "Turizm işletmelerinde bilgi teknolojileri ve dijital dönüşüm: Konya örneği”. Yüksek Lisans Tezi. Selçuk Üniversitesi Sosyal Bilimler Enstitüsü.

47. Cihangir, A. (2019). "Yerel basının dijital dönüşüm tartışmaları". Yüksek Lisans Tezi. Marmara Üniversitesi Sosyal Bilimler Enstitüsü.

48. Öztürk, Ş. (2019). "Bir işletmecilik tecrübesi çerçevesinde dijital dönüşüm modeli önerisi: Enerji sektöründe uygulama ve danışmanlık hizmeti veren bir KOBi örneği". Yüksek Lisans Tezi. Altınbaş Üniversitesi Sosyal Bilimler Enstitüsü.

49. Özduran, R. (2019). "Akıllı çağda dijital dönüşüm bileşenlerinin önceliklendirilmesi ve bir uygulama". Yüksek Lisans Tezi. Bahçeşehir Üniversitesi Fen Bilimleri Enstitüsü. 
50. Güney, B. (2019). “Dijital dönüşümle birlikte ortaya çıkan yeni bağımlılıkların incelenmesi”. Yüksek Lisans Tezi. İstanbul Aydın Üniversitesi Sosyal Bilimler Enstitüsü.

51. Karal, F. S. (2019). “Dijital dönüşümün proje yöneticilerinin yetkinlikleri üzerindeki etkisinin incelenmesi”. Yüksek Lisans Tezi. İstanbul Teknik Üniversitesi Fen Bilimleri Enstitüsü.

52. Hakverdigil, R. K. (2019). "Toplumsal hareketlerin dijital dönüşümü: Slaktivizm üzerine bir araştırma”. Yüksek Lisans Tezi. Marmara Üniversitesi Sosyal Bilimler Enstitüsü.

53. Demirci, E. (2019). “Endüstri 4.0 sürecinde dijital dönüşüm ve sosyoekonomik yansımalar bağlamında insan kaynaklarının dönüşümü: Disiplinlerarası bir yaklaşım”. Yüksek Lisans Tezi. Marmara Üniversitesi Sosyal Bilimler Enstitüsü.

54. Polat, A. S. (2019). "Havacılıkta dijital dönüşüm: İstanbul Havalimanı örneği”. Yüksek Lisans Tezi. Kocaeli Üniversitesi Sosyal Bilimler Enstitüsü.

55. Kosif, F. K. (2019). "Kurumların dijital dönüşüm süreçlerinin incelenmesi: Bir sağlık kurumu için öneri”. Yüksek Lisans Tezi. İstanbul Üniversitesi Fen Bilimleri Enstitüsü.

56. Çeşit, C. K. (2019). “Ödeme hizmetlerindeki dijital dönüşümde rekabet hukukunun rolü". Yüksek Lisans Tezi. Bahçeşehir Üniversitesi Sosyal Bilimler Enstitüsü.

57. Özkaya, M. (2018). "Telekomünikasyon sektöründe dijital dönüşüm”. Yüksek Lisans Tezi. Bahçeşehir Üniversitesi Sosyal Bilimler Enstitüsü.

58. Erbay, H. (2018). "Türk Otomotiv yan sanayisinin dijital dönüşümüne bir yol haritası olarak karışık karar verme modeli”. Yüksek Lisans Tezi. İstanbul Teknik Üniversitesi Fen Bilimleri Enstitüsü.

59. Kökümer, Z. (2018). “Çok kriterli karar verme yöntemleri ile beyaz eşya sektöründe endüstri 4.0 dijital dönüşüm yetkinlik analizi”. Yüksek Lisans Tezi. Kocaeli Üniversitesi Fen Bilimleri Enstitüsü.

60. Sarıyer, K. G. (2013). “Halkla ilişkiler yönetiminde dijital dönüşüm”. Yüksek Lisans Tezi. Kadir Has Üniversitesi Sosyal Bilimler Enstitüsü.

\section{E. "Dijital Ortam" İsmi Geçen Yüksek Lisans Tezleri}

1. Turancı, D. (2020). "1990 sonrası müzik endüstrisine yönelik grafik tasarım ürünlerinin dijital ortamdaki gelişimi”. Yüksek Lisans Tezi. Yeditepe Üniversitesi Sosyal Bilimler Enstitüsü. 
2. Bilgin, E. (2020). “ilköğretim II. Kademe görsel sanatlar dersinde kopya yönteminin geleneksel ve dijital ortamda kullanımına yönelik karşılaştırmalı bir araştırma”. Yüksek Lisans Tezi. Gazi Üniversitesi Eğitim Bilimleri Enstitüsü.

3. Fettahoğlu, B. (2020). "izleyicilerin demografik özelliklerine göre medya okuryazarlığının dijital ortamda paylaşılan haberler bağlamında incelenmesi”. Yüksek Lisans Tezi. İstanbul Kültür Üniversitesi Lisansüstü Eğitim Enstitüsü.

4. Kabasakal, Z. K. (2020). "Mushaf serlevhaları ve dijital ortamda tasarım süreçleri". Yüksek Lisans Tezi. Fatih Sultan Mehmet Vakıf Üniversitesi Lisans Eğitim Enstitüsü.

5. Kocabayık, O. (2019). "İyi kötü kavramların Türk yaratılış destanındaki biçimsel karşılıklarının grafik roman forumda dijital ortama aktarılması". Yüksek Lisans Tezi. Çanakkale Onsekiz Mart Üniversitesi Sosyal Bilimleri Enstitüsü.

6. Konanç, Y. (2019). "Dijital ortamda Ekslibris sanatının gelişimi ve önemi ile sanatçı Martin R. Baeyens'in eserleri ve temsiliyeti". Yüksek Lisans Tezi. Giresun Üniversitesi Sosyal Bilimler Enstitüsü.

7. Albayrak, K. (2019). "Dijital ortamda benlik sunumları üzerine niteliksel bir araştrrma". Yüksek Lisans Tezi. İstanbul Üniversitesi Sosyal Bilimler Enstitüsü.

8. Sırel, A. A. (2019). "Exlibris çalışmalarının sanat ve tasarım açısından geleneksel ve dijital ortamda incelenmesi”. Yüksek Lisans Tezi. İstanbul Arel Üniversitesi Sosyal Bilimler Enstitüsü.

9. Gürsel, D. B. B. (2019). “işe alım sürecinde sosyal medya ile dijital ortamların Y kuşağına etkisi ve insan kaynakları yönetiminin beklentileriyle karşılaştırmalı analizi". Yüksek Lisans Tezi. İstanbul Okan Üniversitesi Sosyal Bilimler Enstitüsü.

10. Demirkaya, D. (2019). “Dijital ortamların halkla ilişkiler amaçlı kullanımı: Kafe ve restoran işletmelerine yönelik nitel bir araştırma”. Yüksek Lisans Tezi. Erciyes Üniversitesi Sosyal Bilimler Enstitüsü.

11. Ünal, S. Z. (2019). "Dijital ortamda gazetecilik ve haber dili". Yüksek Lisans Tezi. İstanbul Üniversitesi Sosyal Bilimler Enstitüsü.

12. Çalışır, G. (2019). "Erzurum çifte minerali medresesinin desen tezyinatının tespiti ve dijital ortama aktarılması". Yüksek Lisans Tezi. Sakarya Üniversitesi Sosyal Bilimler Enstitüsü.

13. Akpınar, M. N. (2019). "Dijital ortamların sanat alanlarına etkisi üzerinden sanal nesne: Vr ve Ar". Yüksek Lisans Tezi. Atatürk Üniversitesi Güzel Sanatlar Enstitüsü. 
14. Sarıbaş, N. (2018). "Dijital ortamda otomobil reklamları üzerine bir inceleme”. Yüksek Lisans Tezi. İstanbul Aydın Üniversitesi Sosyal Bilimler Enstitüsü.

15. Batluralkız, Ç. (2018). "Basılı ve dijital ortamlarda ortaokul öğrencilerinin okuduğunu anlama becerilerinin karşılaştırılması”. Yüksek Lisans Tezi. Dumlupınar Üniversitesi Eğitim Bilimler Enstitüsü.

16. Aktaş, C. (2018). "Eser üzerindeki çoğaltma ile umuma iletim hakkının dijital ortamda ihlali ve hak ihlallerine karşı öngörülen korumalar”. Yüksek Lisans Tezi. İstanbul Bilgi Üniversitesi Sosyal Bilimler Enstitüsü.

17. Korkmaz, E. (2018). “Bahçesaray (Müküs) ve çevresinin etno-botanik özellikleri ve dijital ortama aktarımı”. Yüksek Lisans Tezi. Van Yüzüncü Yıl Üniversitesi Eğitim Bilimleri Enstitüsü.

18. Öztunç, Y. (2018). “Dijital ortam grafik programlarında tipografinin kullanımı”. Yüksek Lisans Tezi. İstanbul Arel Üniversitesi Sosyal Bilimler Enstitüsü.

19. Kayacan, A. (2017). "Yabancı dil olarak İngilizce öğrenen Türk lise öğrencilerinin dijital ortamda yazma ödevleriyle ilgili kendilerine ve akranlarına verdikleri dönütün etkisi". Yüksek Lisans Tezi. Çanakkale Onsekiz Mart Üniversitesi Eğitim Bilimleri Enstitüsü.

20. Köseoğlu, A. (2017). "Yerel gazetecilik bağlamında dijital ortamda yayın yapan yazılı basının incelenmesi: Tekirdağ örneği”. Yüksek Lisans Tezi. Gazi Üniversitesi Sosyal Bilimler Enstitüsü.

21. Güler, Ş. (2016). "Dijital ortamda itibar yöntemi uygulamalarına yönelik bir analiz". Yüksek Lisans Tezi. Marmara Üniversitesi Sosyal Bilimler Enstitüsü.

22. Kurt, M. C. (2016). “Dijital ortamlarda toplumsal katılım anlayışı: Sosyal eylem platformları üzerine bir inceleme”. Yüksek Lisans Tezi. Marmara Üniversitesi Sosyal Bilimler Enstitüsü.

23. Gül, O. (2015). “Dijital ortamda video film estetiği”. Yüksek Lisans Tezi. Marmara Üniversitesi Sosyal Bilimler Enstitüsü.

24. Çarıkçı, T. (2015). “Deutsch Ist Spitze’ Almanca ders kitabının incelenmesi ve dil bilgisi konularının Türkçe ile karşılaştırılarak dijital ortamda pekiştirilmesine ilişkin alıştırma önerileri”. Yüksek Lisans Tezi. Trakya Üniversitesi Sosyal Bilimler Enstitüsü.

25. Köksal, İ. (2015). “Dijital ortamdaki finansal hile kontrolünde adli muhasebe: Bağımsız denetçiler üzerinde bir araştırma”. Yüksek Lisans Tezi. Dumlupınar Üni- 
versitesi Sosyal Bilimler Enstitüsü.

26. Yiğit, H. (2011). "Mimarlıkta dijital ortamın getirdiği tektonik değişim ve formdaki yansımaları”. Yüksek Lisans Tezi. Gazi Üniversitesi Fen Bilimleri Enstitüsü.

27. Aksakal, M. A. (2011). "Güzel sanatlar ve spor liseleri grafik tasarım derslerinde dijital ortam kullanımına ilişkin öğretmen ve öğrenci görüşleri: Diyarbakır örneği". Yüksek Lisans Tezi. Dicle Üniversitesi Sosyal Bilimler Enstitüsü.

28. İnan, N. K. (2010). "Dijital ortamda heykel tasarımı ve uygulamalar". Yüksek Lisans Tezi. Mersin Üniversitesi Sosyal Bilimler Enstitüsü.

29. Akbulut, U. (2009). “Dijital ortamda sanal gerçeklik fotoğraf tekniğinin yeri ve önemi". Yüksek Lisans Tezi. Marmara Üniversitesi Eğitim Bilimleri Enstitüsü.

30. Özkan, Z. C. (2008). "Temel tasarım eğitimi ve dijital ortam". Yüksek Lisans Tezi. Gazi Üniversitesi Eğitim Bilimleri Enstitüsü.

31. Honca, H. (2007). "Exlibris sanat ve dijital ortamda exlibris sanatı uygulamaları”. Yüksek Lisans Tezi. Akdeniz Üniversitesi Sosyal Bilimler Enstitüsü.

32. Gültekin, O. (2006). “İstanbul müftülüğü Meşihat arşivi tarihi belgelerinin dijital ortama aktarılması ve kullanıma sunulması". Yüksek Lisans Tezi. Marmara Üniversitesi Türkiye Araştırmaları Enstitüsü.

33. Gülağaç, Ö. (2005). "Dijital ortamda tasarım ve ifade biçimi olarak temsiliyet kavramı örnek: Mimari proje yarışmaları”. Yüksek Lisans Tezi. İstanbul Teknik Üniversitesi Fen Bilimleri Enstitüsü.

34. Türgan, İ. (2005). "Dijital ortamda tasarımın mekân kavramına ve kurumsal kimlik anlayışına yansımaları”. Yüksek Lisans Tezi. İstanbul Teknik Üniversitesi Fen Bilimleri Enstitüsü.

35. Pak, B. (2003). “Dijital ortam mimari tasarım ara kesitinde bir tasarım modeli”. Yüksek Lisans Tezi. İstanbul Teknik Üniversitesi Fen Bilimleri Enstitüsü.

36. Bilda, Z. (2001). "Kavramsal tasarım aşamasında, geleneksel ve dijital ortamlarda tasarımcıların bilişsel süreçlerinin karşılaştırılması”. Yüksek Lisans Tezi. İhsan Doğramacı Bilkent Üniversitesi Güzel sanatlar Enstitüsü.

37. Günaydın, M. S. (1997). “Dijital ortamda fotoğrafçılık: Fotoğrafik sistemde değişen görsel kavramlar ve basın fotoğrafçılığı üzerindeki etkileri”. Yüksek Lisans Tezi. İhsan Doğramacı Bilkent Üniversitesi Güzel Sanatlar Enstitüsü. 


\section{F. "Dijital Teknoloji" İsmi Geçen Yüksek Lisans Tezleri}

1. Ucay, R. (2020). “Etkileşimli dijital teknolojiler bağlamında beden mekân deneyimi”. Yüksek Lisans Tezi. İstanbul Teknik Üniversitesi Fen Bilimleri Enstitüsü.

2. Samadi, E. (2020). “Dijital teknolojiler ve uluslararası ticaret: Türkiye için SWOT analizi". Yüksek Lisans Tezi. Zonguldak Bülent Ecevit Üniversitesi Sosyal Bilimler Enstitüsü.

3. Konuk, E. (2020). “Dijital teknoloji çağında müzik: Postmodern dönüşüm analizi”. Yüksek Lisans Tezi. Maltepe Üniversitesi Lisansüstü Eğitim Enstitüsü.

4. Vural, ì. (2020). "Spor lisesi öğrencilerinin dijital teknolojiye yönelik tutumlarının incelenmesi". Yüksek Lisans Tezi. Ardahan Üniversitesi Lisansüstü Eğitim Enstitüsü.

5. Amırı, M. H. (2019). “Ankara'da restoranlarda ve kafelerde kullanılan dijital teknoloji uygulamaları hakkında keşfedici bir çalışma". Yüksek Lisans Tezi. Çankaya Üniversitesi Sosyal Bilimler Enstitüsü.

6. Gökdel, M. (2019). “Gelecek tahmin sistemlerine yeni dijital teknolojiler, etkileşim tasarımı ve kişisel destek odaklı bir yaklaşım". Yüksek Lisans Tezi. Yıldız Teknik Üniversitesi Sosyal Bilimler Enstitüsü.

7. Güngör, Z. (2019). “Dijital teknolojilerin giysi ve kumaş tasarımı alanında kullanımı ve yeni öneriler". Yüksek Lisans Tezi. Mimar Sinan Güzel Sanatlar Üniversitesi Sosyal Bilimler Enstitüsü.

8. Aktaş, T. (2019). "Dijital teknolojinin film yapımında tek üretim yöntemine dönüşmesi ve bu dönüşümün etkileri”. Yüksek Lisans Tezi. Mimar Sinan Güzel Sanatlar Üniversitesi Güzel Sanatlar Enstitüsü.

9. Tanoğlu, Ş. (2019). “Resim iş eğitimi öğrencilerinin dijital vatandaşlık düzeyleri ile dijital teknolojiye yönelik tutumları arasındaki ilişkinin incelenmesi”. Yüksek Lisans Tezi. Erzincan Binali Yıldırım Üniversitesi Sosyal Bilimler Enstitüsü.

10. Satılmış, A. (2019). "Türk sigorta işletmelerinde sektör çalışanlarında dijital teknolojiye yönelik tutumların verimliliklerine etkisi". Yüksek Lisans Tezi. Beykent Üniversitesi Sosyal Bilimler Enstitüsü.

11. Korkmaz Z. (2019). “Dijital teknolojileri kullanım alışkanlıkları ve sosyalleşme: Illkokul öğrencileri üzerine bir araştırma”. Yüksek Lisans Tezi. İstanbul Üniversitesi Sosyal Bilimler Enstitüsü.

12. Selçuk, E. B. (2019). “Dijital teknolojilerin özgün baskı resim sanatına etkileri 
ve yeni arayışlar”. Yüksek Lisans Tezi. Afyon Kocatepe Üniversitesi Sosyal Bilimler Enstitüsü.

13. Karaoğlu, S. (2019). "Yaşlı bireylerin dijital teknoloji deneyimlerinin incelenmesi”. Yüksek Lisans Tezi. Mimar Sinan Güzel Sanatlar Üniversitesi Fen Bilimleri Enstitüsü.

14. Belgen, N. (2019). “Dijital teknolojinin çağdaş Türk plastik sanatlarına etkileri”. Yüksek Lisans Tezi. Çanakkale Onsekiz Mart Üniversitesi Sosyal Bilimler Enstitüsü.

15. Somuncuoğlu, S. R. (2019). "21.yy. Bat resim sanatında gelişmekte olan dijital teknolojinin günümüz Türk resim sanatına yansımaları”. Yüksek Lisans Tezi. Mimar Sinan Güzel Sanatlar Üniversitesi Güzel Sanatlar Enstitüsü.

16. Sakarya, R. G. (2019). “Dijital teknolojilerin adli kurumlarda kullanımı: Sorunlar ve firsatlar". Yüksek Lisans Tezi. Marmara Üniversitesi Sosyal Bilimler Enstitüsü.

17. Türkkan, E. (2019). “Algı ilkeleri ışığında op sanat ve dijital teknolojinin olanakları". Yüksek Lisans Tezi. Çanakkale Onsekiz Mart Üniversitesi Sosyal Bilimler Enstitüsü.

18. Baloğlu, U. (2018). “Dijital teknolojilerdeki dönüşümlerin, müzik üretim, tüketim ve paylaşım pratiklerine yansımaları: sosyal medya ve mobil müzik platformları üzerinden bir değerlendirme denemesi”. Yüksek Lisans Tezi. Yıldız Teknik Üniversitesi Sosyal Bilimler Enstitüsü.

19. Erdoğmuş, M. (2017). “Dijital teknoloji çağında baskı resim”. Yüksek Lisans Tezi. Anadolu Üniversitesi Güzel Sanatlar Enstitüsü.

20. Kalaycı, B. (2017). “Kısa film yapımında dijital teknolojilerin kullanımı”. Yüksek Lisans Tezi. Marmara Üniversitesi Sosyal Bilimleri Enstitüsü.

21. Sönmez, G. (2017). "Bağımsız film yapımında dijital teknolojinin kullanımı". Yüksek Lisans Tezi. Marmara Üniversitesi Sosyal Bilimler Enstitüsü.

22. Karabıyık, K. (2016). "Güncel dijital teknolojilerin mobilya tasarım ve üretim aşamasına etkileri”. Yüksek Lisans Tezi. Beykent Üniversitesi Fen Bilimleri Enstitüsü.

23. Ballı, Ö. (2016). "Dijital teknoloji olanaklarıyla sanatta grotesk bedenler ve tuhaflık”. Yüksek Lisans Tezi. Hacettepe Üniversitesi Güzel Sanatlar Enstitüsü.

24. Aslanyürek, Y. (2013). “Dijital teknoloji destekli sinemada yapım sonrası yaratma süreçlerinin incelenmesi". Yüksek Lisans Tezi. Marmara Üniversitesi Güzel Sanatlar Enstitüsü.

25. Kılıç, Y. (2013). “Anadolu liseleri müfredatında yer alan görsel sanatlar dersi- 
nin eğitim öğretim süreçlerinin tasarlanmasında dijital teknolojinin yerine”. Yüksek Lisans Tezi. Ondokuz Mayıs Üniversitesi Eğitim Bilimleri Enstitüsü.

26. Duygun, G. (2010). “Mekânın dijital teknoloji ile arasındaki ilişki: İnteraktif yüzeyler". Yüksek Lisans Tezi. Kocaeli Üniversitesi Fen Bilimleri Enstitüsü.

27. Özdemir, ö. (2010). “Çağdaş sanatta dijital teknolojilerden yararlanan interaktif sanat". Yüksek Lisans Tezi. Erciyes Üniversitesi Güzel Sanatlar Enstitüsü.

28. Araz, Y. (2010). “Çocuk kitaplarını resimlemede dijital teknolojinin kullanılması üzerine bir araşttrma". Yüksek Lisans Tezi. Dokuz Eylül Üniversitesi Eğitim Bilimleri Enstitüsü.

29. Erkal, Ö. O. (1997). "Teknolojinin mimari tasarım üzerinde dönüştürücülüğünün sınırları dijital teknolojilerin tasarım sürecindeki rolü”. Yüksek Lisans Tezi. Orta Doğu Teknik Üniversitesi Fen Bilimleri Enstitüsü.

30. Akman, S. (1997). "Grafik tasarımının oluşturulması ve baskıya dönüştürülmesinde dijital teknolojinin kullanılması". Yüksek Lisans Tezi. Dokuz Eylül Üniversitesi Sosyal Bilimler Enstitüsü.

\section{G. "Dijital Etik" Temalı Doktora Tezleri}

1. Sari, ì. (2019). "Sosyal bilgiler eğitiminde öğretmenlere uygulanan seminer ve öğrencilere yapılan etkinliklerin katkıları bakımından dijital vatandaşlık olgusu." Doktora Tezi. Necmettin Erbakan Üniversitesi Eğitim Bilimleri Enstitüsü.

\section{H. "Dijitalleşme" İsminin Geçtiğini Doktora Tezleri}

1. Myovella, G. A. (2020). "Dijitalleşmenin ekonomik performans etkileri”. Doktora Tezi. Ege Üniversitesi Sosyal Bilimler Enstitüsü.

2. Bitiktaş, F. (2020). "İşletmeden işletmeye pazarlamada dijitalleşme: Deniz taşımacılığının dönüşümü için strateji ve teknolojilerin geliştirilmesi”. Doktora Tezi. Dokuz Eylül Üniversitesi Sosyal Bilimler Enstitüsü.

3. Mutlu, N. (2020). "Dijitalleşme bağlamında yeni medya ve seçmen davranışı ilişkisi: 23 Haziran 2019 yerel seçimleri Küçükçekmece ve Bağcılar örnekleri". Doktora Tezi. İstanbul Gelişim Üniversitesi Lisansüstü Eğitim Enstitüsü.

4. Özkurt, Cem. (2020). "Savunma sanayinde dijitalleşmenin kurumsal niteliklere etkisinin yapay zekâ yöntemleri ile öngörülmesi”. Doktora Tezi. Sakarya Üniversitesi Fen Bilimleri Enstitüsü.

5. Gürsoy, Ö. (2020). "Yalın üretim sisteminde dijitalleşme ve endüstri 4.0 uygu- 
lamaları ile süreç iyileştirme analizi: Bir imalat işletmesinde uygulama". Doktora Tezi. Aydın Adnan Menderes Üniversitesi Sosyal Bilimler Enstitüsü.

6. Güler, Kenan. (2019). "Uluslararası ticaretin dijitalleşmesi ve sanayi akımlarının etkisi: Endüstri 4.0 devrimi üzerine bir araştırma". Doktora Tezi. İstanbul Ticaret Üniversitesi Dış Ticaret Enstitüsü.

7. Ceran, Mustafa. (2019). “Bankacılıkta dijitalleşme kapsamında, öğrenen yapay zekâ desteğiyle sorunlu kredilerin belirlenmesi”. Doktora Tezi. Marmara Üniversitesi Bankacılık ve Sigortacılık Enstitüsü.

8. Delihasan, İ. A. (2017). “Dijitalleşme ve görsellik: Instagram'da beden temsilinin multimodel söylem analizi". Doktora Tezi. Maltepe Üniversitesi Sosyal Bilimler Enstitüsü.

9. Öztürk, B. (2017). "Radyo yayıncılığının dijitalleşmesi ve radyo dinleyicisinin dönüşümü". Doktora Tezi. Marmara Üniversitesi Sosyal Bilimler Enstitüsü.

10. Askeroğlu, E. D. (2017). “Dijitalleşme sürecinde dönüşen kültür ve yaşam tarzları: Kuşaklar üzerine bir tipoloji araştırması". Doktora Tezi. Maltepe Üniversitesi Sosyal Bilimler Enstitüsü.

11. Amann, N. (2017). "Fantastik filmin dijitalleşmesi ve yeniden üretilen göstergelerin çözümlenmesi: Taht Oyunları (Game Of Thrones) örneği”. Doktora Tezi. Maltepe Üniversitesi Sosyal Bilimler Enstitüsü.

12. Bal, Z. E. (2017). "Yükseköğrenimde dijitalleşmenin uzaktan öğrenime etkileri". Doktora Tezi. İstanbul Üniversitesi Sosyal Bilimler Enstitüsü.

13. Zengin, F. (2016). “Dijitalleşmenin Türk Sinemasında yarattğı dönüşüm: Üretim, dağıtım ve gösterim”. Doktora Tezi. İstanbul Üniversitesi Sosyal Bilimler Enstitüsü.

14. Aktaş, S. (2016). “Dijitalleşme ve sinema ilişkisi bağlamında alternatif bir film üretim biçimi olarak kitlesel fonlama ve Türkiye'de kitlesel fonlama uygulamaları”. Doktora Tezi. Marmara Üniversitesi Sosyal Bilimler Enstitüsü.

15. İspir, B. (2008). "Bilgi çağında dijitalleşme ve yeni teknolojiye uyum: Türkiye dijital televizyon yayıncılığı örneği”. Doktora Tezi. Anadolu Üniversitesi Sosyal Bilimler Enstitüsü.

\section{i. 'Dijital Medya' İsminin Geçtiği Doktora Tezleri}

1. Savaş, S. (2020). "İmaj üretiminde dijital medyanın rolü: Kurumların oluşturmaya çalıştıkları imajın tüketiciye ne oranda yansıdığına yönelik bir çalışma”. Doktora Tezi. İstanbul Üniversitesi Sosyal Bilimler Enstitüsü. 
2. Bekman, M. (2020). "Halkla ilişkiler uygulamalarında dijital medyanın kullanımı: Sosyal medya bağımlıı̆̆ının, fomo ve kompülsif çevrim içi satın almada aracılık rolü". Doktora Tezi. Marmara Üniversitesi Sosyal Bilimler Enstitüsü.

3. Türkmen, B. (2019). “Dijital medyanın çeviri eğitimindeki yeri ve dijital medya edinci önerisi”. Doktora Tezi. Sakarya Üniversitesi Sosyal Bilimler Enstitüsü.

4. Demirel, S. D. (2019). “Eleştirel ekonomik politik kuram ışığında dijital medya ile değişen gazetecilik pratikleri: Dijital ve basılı gazeteler üzerine karşılaştırmalı bir çalışma”. Doktora Tezi. Ege Üniversitesi Sosyal Bilimler Enstitüsü.

5. Bulut, S. (2019). "Çokluk mekânı olarak dijital medya ile egemenlik çerçevesinde bilginin kontrolü ve yapısal dönüşümü". Doktora Tezi. İstanbul Üniversitesi Sosyal Bilimler Enstitüsü.

6. Toprak, A. (2019). "Dijital medya ve mekânın dönüşümü”. Doktora Tezi. İstanbul Üniversitesi Sosyal Bilimler Enstitüsü.

7. Ulusoy, A. (2018). “Dijital medya okuryazarlığı, gereksinimler ve yenilikçi uygulamalar üzerine bir inceleme”. Doktora Tezi. Erciyes Üniversitesi Sosyal Bilimler Enstitüsü.

8. Özkan, A. (2016). “Dijital medya ve çocuk: Sosyalleşmenin yeni boyutları”. Doktora Tezi. Sakarya Üniversitesi Sosyal Bilimler Enstitüsü.

9. Karagülle, A. E. (2015). "Kamu diplomasisi aracı olarak dijital medya, dijital diplomasi". Doktora Tezi. Marmara Üniversitesi Sosyal Bilimler Enstitüsü.

10. Şener, N. K. (2015). “Dijital medya teknolojilerinin tekno-sosyoloji bağlamında incelenmesi". Doktora Tezi. İstanbul Üniversitesi Sosyal Bilimler Enstitüsü.

11. Yalçın, Ö. (2015). “Değişen medya ortamında Avrupa'da kamu hizmeti yayıncılığı politikaları ve uygulamaları: Avrupa ekseninden TRT'nin dijital medya uygulamalarının değerlendirilmesi”. Doktora Tezi. Ankara Üniversitesi Sosyal Bilimler Enstitüsü.

\section{J. "Dijital Dönüşüm" İsminin Geçtiği Doktora Tezleri}

1. Yüce, G. (2020). “Dijital dönüşüm ve Endüstri 4.0 olgunluk modeli: Türkiye çimento sektörü üzerine bir uygulama”. Doktora Tezi. Mersin Üniversitesi Sosyal Bilimler Enstitüsü.

2. Sert, E. (2020). “Dijital dönüşümde endüstri 4.0 değer zinciri temel faaliyetler analizi: otomotiv sektörü için model önerisi”. Doktora Tezi. İstanbul Üniversitesi Sosyal Bilimler Enstitüsü. 
3. Özbek, E. A. (2019). “Dijital dönüşümünde öğretim elemanlarının yetiştirilmesi ve geliştirilmesi”. Doktora Tezi. Anadolu Üniversitesi Sosyal Bilimler Enstitüsü.

4. Metin, S. (2019). "İşletmelerin dijital dönüşüm (endüstri 4.0) farkındalık ve algı düzeyinin değerlendirilmesi: Elazığ OSB örneği”. Doktora Tezi. Fırat Üniversitesi Sosyal Bilimler Enstitüsü.

5. Erben, Ş. E. (2019). “Aktivizmin dijital dönüşümü”. Doktora Tezi. Kocaeli Üniversitesi Sosyal Bilimler Enstitüsü.

6. Pakdemirli, B. (2016). “Dijital dönüşümün ekonomik büyümeye etkisi: Türkiye örneği". Doktora Tezi. Celal Bayar Üniversitesi Sosyal Bilimler Enstitüsü.

7. Çelik, N. (2016). "Reklamcılıkta dijital dönüşüm ve uygulamaları üzerine bir inceleme”. Doktora Tezi. İstanbul Üniversitesi Sosyal Bilimler Enstitüsü.

\section{K. "Dijital Ortam" İsmi Geçen Doktora Tezleri}

1. Orçin, G. (2019). "Dijital ortamda baskıcı hoşgörünün üretimi”. Doktora tezi. İstanbul Üniversitesi Sosyal Bilimler Enstitüsü.

2. Kazancı, Z. (2018). "Basılı ve dijital ortamlarda İngilizce metin okuma-anlama yetisi: Karşılaştırmalı bir çalışma”. Doktora tezi. Çukurova Üniversitesi Sosyal Bilimler Enstitüsü.

3. Sezgin, N. (2017). "Dijital ortamda insan yüzlerindeki yaşa bağlı değişimlerin metrik olarak incelenmesi". Doktora Tezi. İstanbul Üniversitesi Adli Tıp Enstitüsü.

4. Kaya, A. (2016). “Dijital ortamlarda hedonik tüketim”. Doktora Tezi. Marmara Üniversitesi Sosyal Bilimler Enstitüsü.

5. Karaduman, H. (2011). “6. Sınıf sosyal bilgiler dersinde dijital vatandaşlığa dayalı etkinlerin öğrencilerin dijital ortamdaki tutumlarına etkisi ve öğrenme öğretme sürecine yansımaları". Marmara Üniversitesi Eğitim Bilimleri Enstitüsü.

\section{L. "Dijital Teknoloji" İsmi Geçen Doktora Tezleri}

1. Seçmen, E. A. (2020). "Sinemada görsel tasarımda dijital teknoloji kullanımının içerikle ilişkisi: Star Wars 'Yıldız Savaşları' filmleri örneği”. Doktora Tezi. İstanbul Üniversitesi Sosyal Bilimler Enstitüsü.

2. Tunç, Ö. A. (2016). “Dijital teknolojiler bağlamında dijital öyküleme yaklaşımının güzel sanatlar eğitimine entegrasyonu". Doktora Tezi. Ondokuz Mayıs Üniversitesi Eğitim Bilimler Enstitüsü. 
3. Avcı, E. (2013). "Dijital sanat bağlamında dijital teknolojilerin güzel sanatlar eğitimine entegrasyonu: Bir eylem araştrrması". Doktora Tezi. Anadolu Üniversitesi Eğitim Bilimler Enstitüsü.

4. Ürper, O. (2009). “Dijital teknolojiye geçişin reklam fotoğrafçılığı uygulamalarına yansımaları: Türkiye'deki reklam fotoğrafçılarının görüşlerinin değerlendirmesi”. Doktora Tezi. Marmara Üniversitesi Sosyal Bilimler Enstitüsü.

\section{M. "Dijitalleşme", "Dijital Medya", "Dijital Ortam" ve "Dijital Teknoloji" İsimle- ri Geçen Tıpta Uzmanlık ve Sanatta Yeterlik Tezleri}

1. Tire, S. (2018). "Sanat ve dijital teknoloji ilişkisinde dijital resim”. Sanatta Yeterlik. Çukurova Üniversitesi Sosyal Bilimler Enstitüsü.

2. Eren, E. (2012). "Sinema kültür mirasının korunması ve dijital teknolojik gelişmelerin film arşivciliğine etkileri". Sanatta Yeterlik. Mimar Sinan Güzel Sanatlar Üniversitesi Sosyal Bilimler Enstitüsü.

3. Yalur, E. (2019). "Dijital ortamdaki masal kitaplarının grafik tasarımlarının incelenmesi”. Sanatta Yeterlik. İstanbul Arel Üniversitesi Sosyal Bilimler Enstitüsü.

4. İnan, I. (2006). “Dijital ortamda temel sanat eğitimi”. Sanatta Yeterlik. Marmara Üniversitesi Güzel Sanatlar Enstitüsü.

5. Toksoy, K. (2018). “Dijital medyanın 18 ay - 3 yaş arasındaki çocukların gelişimine katkısı”. Tıpta Uzmanlık. Gazi Üniversitesi Tıp Fakültesi Çocuk Sağlığı ve Hastalıkları Ana Bilim Dalı Çocuk Nörolojisi Bilim Dalı.

6. Ballı, Ö. (2020). “Günümüz sanatında dijitalleşme; Posthümanizm bağlamında sanat ve sanatçının yerini alan algoritma: Post-sanatçı." Sanatta Yeterlik. Hacettepe Üniversitesi Güzel Sanatlar Enstitüsü.

\section{Kaynakça}

"Dijital Türkiye Yol Haritası". Türkiye Cumhuriyeti Bilim, Sanayi ve Teknoloji Bakanlığı. (2018). 30.04.2021Tarihinde https://www.gmka.gov.tr/dokumanlar/yayinlar/2023_Dijital-Turkiye-Yol-Haritasi.pdf adresinden edinilmiştir.

Elçi, A. C. (2015). 'Bilişim teknolojileri ve yazılı dersi öğretim programına yönelik öğrenci görüşlerinin dijital vatandaşlık bağlamında incelenmesi.' Yüksek Lisans Tezi. Çukurova Üniversitesi Sosyal Bilimler Enstitüsü. 
Gölge, A. B. (2017). 'Benliğin Instagram'da çevrim içi sunumu: Türkiye'deki yoga topluluğu örneği.' Yüksek Lisans Tezi. İhsan Doğramacı Bilkent Üniversitesi Ekonomi ve Sosyal Bilimler Enstitüsü.

Karabağ, K. (2001). 'Mutlak mekân: MUD, mimari mekânın yeniden kavramsallaştırılması yolunda bir öneri.' Yüksek Lisans Tezi. Orta Doğu Teknik Üniversitesi Fen Bilimleri Enstitüsü.

"On Birinci Kalkınma Planı (2019-223)". Türkiye Cumhuriyeti Cumhurbaşkanlığı Strateji ve Bütçe Başkanlığı. (2018). 30.04.2021 Tarihinde' https://www.sbb.gov.tr/ kalkinma-planlari/

Sari, ì. (2019). 'Sosyal bilgiler eğitiminde öğretmenlere uygulanan seminer ve öğrencilere yapılan etkinliklerin katkıları bakımından dijital vatandaşlık olgusu.' Doktora Tezi. Necmettin Erbakan Üniversitesi Eğitim Bilimleri Enstitüsü.

“Türkiye'nin Dijital Dönüşüm Endeksi 2020’ Tübsiad, (2020). 30.04.2021 tarihinde http:// www.tubisad.org.tr/tr/images/pdf/tubisad-dde-2020.pdf

"Türkiye'nin Dijitalleşme Endeksi". Türkiye Bilişim Vakf, (2015). 30.04.2021 Tarihinde http://tbv.org.tr/en-dijital-100-endeks-calismasi/ 